\title{
Nuclear Weapons in the 112th Congress: Politics and Policy after New START
}

Thomas Karako, Kenyon College

ABSTRACT Passed by the US House of Representatives as part of the annual defense authorization bill in May 2011, provisions of the New START Implementation Act (NSIA) represented an attempt by Congress to exercise more robust involvement in US nuclear policy, an area historically subject to a great deal of deference to the executive branch. The bill sought to implement the "grand bargain" that preceded the ratification of the New START treaty-namely, that the treaty's seven-year window of reductions to US nuclear forces should be made in tandem with a 10-year modernization program of both the weapons themselves and their aging delivery systems. The context of this arrangement was growing concern about the ability of the United States to retain a sustainable nuclear deterrent for the indefinite future. Although the NSIA provisions were abandoned during conference with the Senate in December 2011, their underlying concerns remain unresolved, and the sustainability of the nuclear enterprise is certain to reappear as a future point of controversy.

\section{A} s of September 30, 2009, the United States' nuclear stockpile consisted of 5,113 warheads-the first public accounting of the stockpile in US history. This number represents an $84 \%$ reduction from the US high of more than 31,255 in 1967 , more than a $75 \%$ reduction since the fall of the Berlin Wall (22,217 in 1989), and approximately half the size of the stockpile since the beginning of the Bush presidency $(10,526$ in 2001) (Department of Defense 2010a). The post-Cold War years also witnessed a considerable constriction of the physical facilities and personnel devoted to the civilian nuclear enterprise and military mission. The administrations of both George W. Bush and Barack Obama pledged to move beyond Cold War deterrence thinking and to reduce the role of nuclear weapons in our national security strategy. But both administrations also were committed to retain a nuclear deterrent for as long as nuclear weapons were needed. Despite a changed geopolitical environment and a greater reliance on conventional forces, the basic purpose of nuclear weapons has remained substantially constant even since before the end of the Cold War. In the words of former secretary of defense James Schlesinger,

Thomas Karako is an assistant professor of political science at Kenyon College. He was an APSA Congressional Fellow, class of 2011-12, for the US House of Representatives Armed Services Committee. He can be reached at KarakoT@kenyon.edu.
We sometimes hear or read the query, "Why are we investing in these capabilities which will never be used?" This is a fallacy. A deterrent, if it is effective, is in "use" every day. The purpose in sustaining these capabilities is to be sufficiently impressive to avoid their "use"-in the sense of the actual need to deliver the weapons to targets (Schlesinger 2009, 12).

In recent years, a series of reports have documented how the shrinking post-Cold War nuclear infrastructure is plagued with serious physical and personnel issues, both military and civilian, as well as a troubling lack of attention, focus, and importance to both the military's nuclear mission and the domestic nuclear enterprise writ large, resulting in an uncertain future for the sustainability of the US nuclear deterrent (Chiles 2008; Schlesinger 2008). That the military's nuclear mission had come to be taken for granted was confirmed with two embarrassing incidents: first, when four nuclear weapon fuses were accidentally transported to Taiwan in 2006, and second, in 2007, when actual nuclear weapons went missing for 36 hours after having been flown from North Dakota to Louisiana without authorization.

These growing concerns culminated in the 2009 report of a bipartisan blue-ribbon congressionally mandated commission, headed by former secretaries of defense William Perry and James Schlesinger. The Strategic Posture Commission warned of an "atrophying" and "decrepit" nuclear enterprise and the need to 
renew nuclear production capabilities and deterrence skills (Perry and Schlesinger 2009). The weapons themselves require costly and time-consuming life-extension programs (LEPs) to remain reliable, but the ability to perform these LEPs has fallen dramatically. The National Nuclear Security Administration (NNSA)run plutonium pit facility in Los Alamos, New Mexico, sits atop a major earthquake fault; the uranium facility in Oak Ridge, Tennessee, dates to the Manhattan Project. Both facilities need to be replaced-each at the cost of billions of dollars. Significant capital costs would also be required to replace or modernize the delivery vehicles for these weapons-including strategic bombers dating to the Cold War, Minuteman III ballistic missiles, sea-launched Trident missiles, the aging Ohio-class nuclear submarines, and nuclear-capable cruise missiles. To fix the nuclear enterprise, secretary of defense Robert Gates transferred $\$ 8.3$ billion in top-line budget authority from the Department of Defense to the NNSA over five years-no casual act in a period of tightened budgets.

The condition of the US nuclear enterprise played an important, but hitherto underappreciated, part of the ratification debate for the New Strategic Arms Reduction Treaty (New START). When New START was finally confirmed by the Senate, it was only after the Obama administration laid out a new plan to remedy some of the well-established problems with the nuclear enterprise. Although exacted as a political "grand bargain" by the Senate, the basic idea that nuclear cuts should proceed in tandem with nuclear modernization is firmly rooted in the technical realities of the post-Cold War hedging strategy implemented by the Clinton administration. The Senate's approval of New START in December 2010, at the close of the 111th Congress, reflected those promises about the future of the US nuclear arsenal and modernization of the US strategic nuclear enterprise, and the resolution of ratification called for their implementation. The Obama administration committed to sustaining and modernizing the nuclear arsenal, seeking $\$ 7.6$ billion in its FY2012 budget request for nuclear weapons activities and pledging a total of $\$ 189$ billion over the next decade for both weapons and delivery vehicles.

This commitment came in part in the updated " 1251 report" of November 2010 (named for the section number of the FY2010 defense act requiring it). In this report the administration described the problems and acknowledged that its commitment and increased budget requests were with full awareness of the larger fiscal restrictions: "given the extremely tight budget environment facing the federal government, these requests to the Congress demonstrate the priority the Administration places on maintaining the safety, security, and effectiveness of the deterrent" (Executive Office of the President 2010, 2).

In short, commitment to modernization of both weapons and delivery systems enabled cuts in the stockpile-cuts that if enacted in the absence of modernization, would call into question the US ability to meet its deterrence requirements. Subsequent administration statements after New START ratification, however, indicated that the administration was considering much deeper cuts irrespective of the promised modernization progress.

These facts set the stage for the 112th Congress, and the sort of issues that helped shaped the discussion, oversight, hearings, and legislation of the House and Senate subcommittees on Strategic Forces. In early 2011, the Armed Services committees of both the Democratic-controlled Senate and the Republican-controlled House held hearings on the post-New START environment on plans to implement the promised nuclear modernization and on reports that the administration planned to make still deeper cuts, below New START levels.

Over the ensuing months, executive-congressional politics, budget disputes, and the administration's eagerness for still deeper arms control reductions, began to draw that grand bargain into serious doubt. As a result, members of both the House and the Senate introduced two nearly identical bills called "The New START Implementation Act" or "NSIA" (H.R. 1750/S.B. 1097).

Reaffirming the importance of modernization expressed in the Senate's resolution of ratification, the NSIA bill linked deeper reductions with nuclear modernization, both during the life of the treaty and beyond it, as well as paving the way for greater congressional involvement and oversight in future reduction of the nuclear stockpile. According to the provisions, the executive branch would be prohibited from unilaterally reducing, retiring, or dismantling weapons in the stockpile, except pursuant to law, either a treaty or statute. It would have altered the deference to unilateral executive branch preferences, which is perhaps appropriate with a much smaller and aging stockpile.

In the House, most of the NSIA provisions were incorporated into the annual national defense authorization act for fiscal year 2012 (H.R. 1540), and were then passed by the House of Representatives. Shortly after passage, the Obama administration threatened to veto the annual defense bill if it contained several of the NSIA provisions (Executive Office of the President 2011). When the Senate passed its version of the defense authorization act for FY2012, it lacked comparably robust provisions of the NSIA, but importantly did touch upon many of the House's concerns, in the form of reporting requirements. Following a conference between the House and Senate in December 2011, the compromise bill dropped the more restrictive legislative mechanisms, but in return slightly increased funding authorization for the nuclear modernization programs. The post-conference compromise act was signed into law by President Obama on December 31, 2011.

In the fall of 2011, the Department of Defense began to review deterrence requirements and nuclear employment guidance for the specific purpose of creating "options" for "deeper" and "dramatic" reductions below New START levels (Donilon 2011; Tauscher 2011; Department of Defense 2010b). If, as it currently appears, the modernization-for-cuts grand bargain of 2010 is not fully implemented, it could adversely affect both the future prospects for nuclear reductions and, more generally, inter-branch trust. In short, all of the concerns that prompted the NSIA are likely to remain in place for years to come.

\section{AFTER NEW START}

In Prague on April 5, 2009, President Barack Obama pledged substantial reductions in the US nuclear arsenal, offering "America's commitment to seek the peace and security of a world without nuclear weapons," but added that "This goal will not be reached quickly-perhaps not in my lifetime" (Obama 2009). A year later, in April 2010, the administration released a new Nuclear Posture Review (NPR), the third since 1994, stating that "changes in the nuclear threat environment have altered the hierarchy of our nuclear concerns and strategic objectives." The NPR added that these recent changes would enable the United States to move to "significantly lower nuclear force levels and with reduced reliance on nuclear weapons" (Department of Defense 2010b). At the Prague signing ceremony for New START that same 
month, President Obama reaffirmed his hope that the treaty would "set the stage" for further and "more significant cuts" (Obama 2010).

Although describing a vision of ultimate elimination, Obama reaffirmed that as long as nuclear weapons existed in the world, the United States would retain a strong nuclear deterrent: "Make no mistake: As long as these weapons exist, the United States will maintain a safe, secure and effective arsenal to deter any adversary, and guarantee that defense to our allies."

Releasing its report in May 2009, the Commission on the Strategic Posture of the United States reached conclusions of similar balance. Headed by former secretaries of defense William Perry and James Schlesinger, the commission judged that "the United States will need to sustain a deterrent for the indefinite future." With respect to the twin goals of eventual elimination and indefinite deterrence articulated by President Obama in Prague, the reductions in US forces could have yet-unanticipated and unintended consequences for strategic stability and balanced nuclear postures; indeed, "The challenges of finding stabilizing, balanced postures will become only more pronounced as deeper reductions require the participation of additional states" (Perry and Schlesinger 2009, 66-67).

\section{THE STOCKPILE AND NEW START}

The 5,113 weapons in the stockpile in 2009 included both deployed and nondeployed weapons. Only the former have been hitherto restricted by international treaties; nondeployed weapons, and thus the number of the total stockpile, have never been restricted by treaty. Of the 5,113 or so warheads in the stockpile in late 2009, the slightly different counting rules of the Moscow Treaty of 2002, in principle, would have allowed up to 2,200 warheads to be deployed at any time. As of 2008 , the deployed nuclear force lev-

\section{Although describing a vision of ultimate elimination, Obama reaffirmed that as long as nuclear weapons existed in the world, the United States would retain a strong nuclear deterrent: "Make no mistake: As long as these weapons exist, the United States will maintain a safe, secure and effective arsenal to deter any adversary, and guarantee that defense to our allies."}

commission observed that "conflicts or trade-offs" could arise, and therefore it urged a careful balance:

a U.S. policy agenda that seems to stress unnecessarily our nuclear weapon posture could erode international cooperation to reduce nuclear dangers. Conversely, a policy agenda that emphasizes unilateral reductions could weaken the deterrence of foes and the assurance of allies. It is necessary to strike a balance in meeting these two imperatives (Perry and Schlesinger 2009, 15).

Although some have characterized the Prague vision as a radical departure from the past, former secretary of defense William Perry writes that it instead is merely "the most recent formulation of the 'lead but hedge' policy" articulated by President Clinton in the 1994 Nuclear Posture Review (Perry 2009). This basic attitude also remained consistent with the Bush administration. As secretary of defense Robert Gates explained in 2008, "President Clinton called his nuclear arms reductions part of a lead and hedge strategy: we'll lead the way in reducing our arsenal, but we must always hedge against the dangerous and unpredictable world. That is still true today and maybe even more so" (Gates 2008).

The commissioners expressed concerns about the complete elimination of nuclear weapons: "The conditions that might make possible the global elimination of nuclear weapons are not present today and their creation would require a fundamental transformation of the world political order." The commission further noted that while the "nuclear deterrent of the United States need not play anything like the central role that it did for decades in U.S. military policy and national security strategy," it nevertheless "remains crucial for some important problems." Moreover, the road to deep reductions could incur numerous challenges, and these challenges had still yet to be explored. Furthermore, deeper els of the United States were reportedly already below the 2,200 threshold, and represented the lowest levels of deployed weapons since the Eisenhower administration (Perry and Schlesinger 2009, 5) (see table 1).

Signed on April 8, 2010, and approved by the Senate on December 22, the New START treaty entered into force on February 5 , 2011. Under the terms of the treaty, the United States and Russia will be limited to lower legal limits on delivery vehicles and deployed warheads within seven years from the date the treaty enters into force, specifically:

- A limit of 1,550 deployed strategic nuclear warheads. Each warhead on deployed intercontinental ballistic missile (ICBMs) and deployed submarine launched ballistic missiles (SLBMs) counts toward this limit and each deployed heavy bomber equipped for nuclear armaments counts as one warhead toward this limit.

- A combined limit of 800 deployed and nondeployed ICBM launchers, SLBM launchers, and heavy bombers equipped for nuclear armaments.

- A separate limit of 700 deployed ICBMs, deployed SLBMs, and deployed heavy bombers equipped for nuclear armaments.

The pace at which the United States reduces its deployed forces to comply with the New START treaty still had not been determined as late as January 2012, but appears unlikely to begin even during fiscal year 2013.

Some have predicted that under current plans, the number of weapons in the US stockpile could decline from the 5,113 warheads reported in 2009 to around 4,600 warheads in or around 2012 (Kristensen et al. 2009, 13). The currently planned cuts to 
Table 1

US Stockpile Numbers-End of Fiscal Years 1962-2009

\begin{tabular}{ll|ll|rr|rr}
$\mathbf{1 9 6 2}$ & 25,540 & $\mathbf{1 9 7 4}$ & 28,537 & $\mathbf{1 9 8 6}$ & 23,317 & $\mathbf{1 9 9 8}$ & 10,732 \\
\hline $\mathbf{1 9 6 3}$ & 28,133 & $\mathbf{1 9 7 5}$ & 27,519 & $\mathbf{1 9 8 7}$ & 23,575 & $\mathbf{1 9 9 9}$ & 10,685 \\
\hline $\mathbf{1 9 6 4}$ & 29,463 & $\mathbf{1 9 7 6}$ & 25,914 & $\mathbf{1 9 8 8}$ & 23,205 & $\mathbf{2 0 0 0}$ & 10,577 \\
\hline $\mathbf{1 9 6 5}$ & 31,139 & $\mathbf{1 9 7 7}$ & 25,542 & $\mathbf{1 9 8 9}$ & 22,217 & $\mathbf{2 0 0 1}$ & 10,526 \\
\hline $\mathbf{1 9 6 6}$ & 31,175 & $\mathbf{1 9 7 8}$ & 24,418 & $\mathbf{1 9 9 0}$ & 21,392 & $\mathbf{2 0 0 2}$ & 10,457 \\
\hline $\mathbf{1 9 6 7}$ & 31,255 & $\mathbf{1 9 7 9}$ & 24,138 & $\mathbf{1 9 9 1}$ & 19,008 & $\mathbf{2 0 0 3}$ & 10,027 \\
\hline $\mathbf{1 9 6 8}$ & 29,561 & $\mathbf{1 9 8 0}$ & 24,104 & $\mathbf{1 9 9 2}$ & 13,708 & $\mathbf{2 0 0 4}$ & 8,570 \\
\hline $\mathbf{1 9 6 9}$ & 27,552 & $\mathbf{1 9 8 1}$ & 23,208 & $\mathbf{1 9 9 3}$ & 11,511 & $\mathbf{2 0 0 5}$ & 8,360 \\
\hline $\mathbf{1 9 7 0}$ & 26,008 & $\mathbf{1 9 8 2}$ & 22,886 & $\mathbf{1 9 9 4}$ & 10,979 & $\mathbf{2 0 0 6}$ & 7,853 \\
\hline $\mathbf{1 9 7 1}$ & 25,830 & $\mathbf{1 9 8 3}$ & 23,305 & $\mathbf{1 9 9 5}$ & 10,904 & $\mathbf{2 0 0 7}$ & 5,709 \\
\hline $\mathbf{1 9 7 2}$ & 26,516 & $\mathbf{1 9 8 4}$ & 23,459 & $\mathbf{1 9 9 6}$ & 11,011 & $\mathbf{2 0 0 8}$ & 5,273 \\
\hline $\mathbf{1 9 7 3}$ & 27,835 & $\mathbf{1 9 8 5}$ & 23,368 & $\mathbf{1 9 9 7}$ & 10,903 & $\mathbf{2 0 0 9}$ & 5,113 \\
\hline $\mathbf{S}$ & & & & & & &
\end{tabular}

Source: Department of Defense 2010a.

nondeployed weapons prior to around 2021-23 would probably consist of only a few hundred warheads; more significant cuts to the stockpile are contingent on the implementation of a responsive nuclear infrastructure. The marginal cost of retaining such an additional number of warheads over that period (as opposed to retiring them) is relatively small, estimated to be in the tens of millions of dollars (Cartwright 2010).

To be clear, however, of the nuclear weapons classified as "operationally deployed" for legal treaty purposes, most are not on alert and responsive to presidential orders. Referencing the limit of 1,700-2,200 operationally deployed strategic nuclear weapons set by the 2002 Moscow Treaty, a 2008 report jointly issued by the secretaries of defense and of energy noted that the actual day-today number is "much smaller," and that it could take "a few weeks to months" to bring up to day-to-day operational availability even the full figure of operationally deployed nuclear weapons permitted by the treaty:

Strategic nuclear warheads available on a day-to-day basis provide a spectrum of targeting options for consideration during rapidly developing, high-stakes contingencies. This force, much smaller than the 1,700 to 2,200 ODSNW [operationally deployed strategic nuclear weapons], and routinely deployed and responsive to orders only from the President, serves immediate deterrence and defeat goals. However, should unexpected developments pose a more imminent threat, the projected day-today alert force could be increased relatively quickly (a few weeks to months) up to the baseline ... (Department of Defense, Department of Energy 2008).

Some nongovernmental experts have estimated that, under current alert postures and guid- ance, the force of operationally deployed strategic warheads on alert and actually available for immediate deterrence and defeat goals has, on a given day, been closer to 900 weapons (Kristensen et al. 2009, 12).

Data exchanged shortly after the ratification of New START confirmed that although the United States will have to make reductions in both deployed nuclear warheads and delivery vehicles to reach New START levels, Russia will have to make much more modest cuts, and only in the category of nondeployed delivery vehicles (see table 2). Specifically, the United States will need to reduce:

- deployed delivery vehicles (ICBMs, SLBMs, and bombers) by 182 to reduce from 882 to meet the treaty's limit of 700 deployed delivery vehicles;

- the aggregate of deployed and nondeployed delivery vehicles by 324 , to reduce from 1,124 to the treaty limit of 800 ; and

- deployed nuclear weapons from 1,800 by 250 to reach treaty the limit of 1,550 .

A data exchange after the treaty's entry into force on February 5, 2011, also revealed that the Russian Federation will have to make almost no reductions to meet New START levels. According to the counting rules of the treaty, Russian both deployed delivery vehicles and deployed warheads were already below New START levels. Russia will, however, have to make some modest reductions to its aggregate total of deployed and nondeployed delivery vehicles.

\section{WHY A NONDEPLOYED HEDGE?}

Significantly, the New START treaty did not restrict or reduce numbers of nondeployed nuclear warheads (nor, indeed, had previous arms control treaties before it). Since then, however, the administration has indicated that post-New START negotiations may include them, thus reducing the total stockpile below current levels. On March 29, 2011, national security adviser Tom Donilon stated that the administration believes "the next agreement with Russia ... should include both non-deployed and nonstrategic
Table 2

\section{US and Russian Deployed Warheads and Delivery Vehicles as of February 5, 2011}

\begin{tabular}{lcccc} 
CATEGORY & $\begin{array}{c}\text { UNITED } \\
\text { STATES }\end{array}$ & $\begin{array}{c}\text { RUSSIAN } \\
\text { FEDERATION }\end{array}$ & $\begin{array}{c}\text { ALLOWED UNDER } \\
\text { NEW START }\end{array}$ & $\begin{array}{c}\text { NUMBER TO REDUCE } \\
\text { (U.S./RUSSIA) }\end{array}$ \\
\hline $\begin{array}{l}\text { Deployed ICBMs, Deployed SLBMs, } \\
\text { and Deployed Heavy Bombers }\end{array}$ & 882 & 521 & 700 & 182/NA \\
\hline $\begin{array}{l}\text { Warheads on Deployed ICBMs, on Deployed } \\
\begin{array}{l}\text { SLBMs, and Nuclear Warheads Counted } \\
\text { for Deployed Heavy Bombers }\end{array}\end{array}$ & 1,800 & 1,537 & 1,550 & $250 /$ NA \\
\hline $\begin{array}{l}\text { Deployed and Nondeployed Launchers of } \\
\text { ICBMs, Deployed and Nondeployed Launchers } \\
\text { of SLBMs, and Deployed and Nondeployed } \\
\text { Heavy Bombers }\end{array}$ & 1,124 & 865 & 800 & $324 / 65$ \\
\hline
\end{tabular}


nuclear weapons" (Donilon 2011). If implemented prior to the creation of a responsive nuclear infrastructure, however, deeper cuts could begin to call into question US deterrent commitments.

The US nuclear stockpile contains a substantial number of nondeployed weapons to "hedge" against technical and geopolitical uncertainties. Should a systemic technical failure affect an entire class of warheads, or geopolitical events warrant an increased deployment of warheads, nondeployed warheads could be deployed and "uploaded" onto existing nuclear delivery systems (e.g., missiles, bombers, submarines) to compensate. This long-established practice continues an approach used since the end of the Cold War to ensure a robust deterrent force without the need for nuclear explosive testing. The Clinton administration's 1994 Nuclear Policy Review articulated a "lead but hedge" strategy to making deep post-Cold War cuts in deployed forces while retaining substantial nondeployed forces. During the Cold War, the nondeployed stockpile was less important, because the United States maintained and continually used a robust production capability for nuclear warheads. The number of deployed and nondeployed US nuclear weapons has been reduced dramatically over the years, but the existence and basic rationale for the nondeployed stockpile, as a means to mitigate risk, has continued.

Factors unique to the United States make reductions in nondeployed forces of relatively greater significance for the United capability, a smaller hedge incurs greater risk than a larger one. As Nuclear Matters further explains,

In the absence of a modernized nuclear infrastructure and the reestablishment of a fissile component production capability (with sufficient capacity), the decision to reduce the size of the hedge and dismantle additional weapons is final and cannot be reversed. Once the weapons are gone, the total stockpile number is permanently decreased until the United States can produce replacements-using a production process whose construction and deployment time to a first weapon could take two decades or longer (Department of Defense 2011).

Indeed, over time, and even without reductions, the risks involved with the aging nondeployed force will naturally increase. The September 2008 report issued by the Department of Defense and Department of Energy adds that,

The United States has not designed a new nuclear warhead since the 1980 s and has not built a new warhead since the early 1990s. As a result, the nuclear weapons infrastructure has atrophied and existing U.S. nuclear weapons-most of which were designed 20 to 30 years ago-are being maintained well beyond the service life for which they were designed. Critical personnel, with experience in the design and testing of nuclear weapons, are also aging and retiring, and in

\section{Significantly, the New START treaty did not restrict or reduce numbers of nondeployed nuclear warheads (nor, indeed, had previous arms control treaties before it).}

States, as compared to Russia or other nuclear powers. As explained in the updated 2011 edition of The Nuclear Matters Handbook,

There are two basic approaches to nuclear stockpile risk mitigation: the existence of a significant warhead production capability, the maintenance of warheads designated as hedge weapons, or some combination of the two. During the Cold War, the United States maintained a robust production capability to augment or decrease production, as required, depending on operational and geopolitical requirements. Today, the United States does not have an active nuclear weapon production capability and relies on the maintenance of a warhead hedge to reduce risk to acceptable levels (Department of Defense 2011).

Elaborating on the role of a nondeployed hedge force for the United States, a September 2008 joint report by the Department of Defense and the Department of Energy notes that "the United States is now the only nuclear weapons state party to the NPT [Nuclear Nonproliferation Treaty] that does not have the capability to produce a new nuclear warhead" (Department of Defense and Department of Energy 2008, 19; emphasis in original). Instead of a Stockpile Stewardship Program to maintain the existing stockpile by means of advanced modeling, simulation, experiments, and surveillance, Britain, France, Russia, and China retain the means to replace old nuclear warheads or create new ones. Whereas these countries use production capability to serve as a kind of hedge, the United States remains heavily reliant on a large number of older nondeployed nuclear forces (Perry and Schlesinger $2009,14)$. In the absence of even a modest or "trickle" production the absence of a viable nuclear infrastructure, their expertise cannot be replaced. Moreover, as new design efforts are further delayed, the ability and availability of experienced designers and engineers to mentor the next generation will decrease over time.... The hedging strategy adopted by the United States for mitigating geopolitical and technical risks by retaining a significant number of reserve warheads is a direct result of the events of the 1980 s and early 1990 s and the atrophy of the nuclear infrastructure.

In short, the post-Cold War moratorium on nuclear testing and the lack of a production capability means that "The process of modernize and replace became one of retain and maintain" (Department of Defense 2011). For weapons that were originally designed to have a life span of perhaps only some 20 years, however, "retain and maintain" strategies have their limits.

The nuclear arsenal has been annually certified as safe, secure, and reliable on the basis of the Stockpile Stewardship Program, insights into the aging issues affecting nuclear warheads, and stockpile surveillance. The "retain and maintain" path, however, is not without limitations:

As the stockpile ages and becomes both smaller and less diverse in terms of the number of warhead types that are deployed, there is inevitably less flexibility to adjust for technical failures that could arise. Any concerns that develop about stockpile safety and reliability become even more pressing (Department of Defense and Department of Energy 2008, 24).

Delays further compound the risk: "The capability and credibility of the nation's deterrent is particularly sensitive to technical 
problems that could render a warhead unacceptable" (Department of Defense and Department of Energy 2008, 24). Experience has confirmed the need to hedge against technical risks. A Department of Energy-sponsored study from the early 1980 os suggests that "at times in the past, the warheads for a large part of the U.S. [ballistic missile submarine] force have been found to be badly deteriorated. At different times, a large fraction of the warheads either obviously or potentially would not work; they were obvious or potential duds" (Rosengren 1983; Pincus, 1978). The 2009 Strategic Posture Commission was more explicit. Although the commission judged that the United States must maintain a nuclear deterrent for "the indefinite future," it noted that the current approaches, although praiseworthy, had limits: "The Stockpile Stewardship Program and the Life Extension Program have been remarkably successful in refurbishing and modernizing the stockpile to meet these criteria, but cannot be counted on for the indefinite future." The commission adds that the Stockpile Stewardship and Life Extension programs "will become more the grand bargain for New START, and keeping the bargain on track was the foremost purpose of the New START Implementation Act.

In short, two basic relationships that have informed the need for a nondeployed hedge and the size of the nuclear stockpile remain unchanged since the end of the Cold War:

- the need to hedge against geopolitical and technical uncertainties (as noted in the 1994, 2001, and 2010 Nuclear Policy Reviews); and

- the relationship between the potential for hedge reductions and a responsive infrastructure (noted in the "New Triad" of the 2001 Nuclear Policy Review and reaffirmed in 2010).

Implementing the responsive nuclear infrastructure promised prior to ratification of New START would allow further reductions of the total nuclear stockpile-deeper cuts than would otherwise be prudent.

\section{Regardless of the larger enterprise, the hedge force itself has a finite lifetime, and relying on thousands of weapons is both unsustainable and undesirable for those who would prefer deeper reductions, on the part of both the United States and Russia.}

difficult as the weapons age" (Perry and Schlesinger 2009, 12, xvii, xii; Department of Defense and Department of Energy 2008).

Regardless of the larger enterprise, the hedge force itself has a finite lifetime, and relying on thousands of weapons is both unsustainable and undesirable for those who would prefer deeper reductions, on the part of both the United States and Russia. The indefinite reliance on the reserve or hedge force "highlights the urgency of getting on with the task of restoring a responsive and capable nuclear weapons infrastructure" (Department of Defense and Department of Energy 2008). Furthermore,

Until a truly responsive nuclear infrastructure is operational, however, the United States will need to retain an appropriate inventory of non-deployed warheads to manage geopolitical, technical and operational risks.... In the long-term, the goal is for the United States to rely more on a revived nuclear infrastructure to respond to unforeseen events, and less on reserve warheads in the stockpile. However, until there is confidence in the infrastructure's demonstrated capability to respond to unexpected developments by producing nuclear weapon components in sufficient quantities, especially plutonium pits, the United States will need to retain more reserve warheads than otherwise would be desired as a hedge against technical problems or adverse geopolitical changes (Department of Defense and Department of Energy 2008).

As noted by the 2010 Nuclear Posture Review (NPR), the numbers of hedge weapons necessary could be diminished with the "implementation" of the major infrastructure identified by the NPR, including the new plutonium and uranium facilities (Department of Defense 2010b, 30). The 2010 NPR's identification of these needs was similar to the calls for a "responsive infrastructure" found in the 2001 NPR and the Commission on the Strategic Posture of the United States (Perry and Schlesinger 2009). Creating this responsive infrastructure represents the heart of
One concern, however, is that the executive branch could choose to redefine US deterrence requirements down-accepting greater technical risk, changed targeting strategies, or different assumptions about future geopolitical conditions-in such a way as to render the need for a responsive infrastructure seemingly less urgent. The deterrence review begun in late 2011, which is expected to be completed before the FY2013 budget request, could do just this. Described as taking place for the express purpose of creating options for future nuclear reductions, will reportedly include "alternative approaches ... to hedging." Because the deterrence review has been expressly described as a means to identify possible deeper cuts, a redefinition of US deterrence strategy could create substantial concern about the sustainability of the US deterrent (Miller 2011).

\section{A SUSTAINABLE NUCLEAR DETERRENT}

All the relevant parties have been in remarkable agreement about the basic outlines of what the head of the National Nuclear Security Administration (NNSA) Tom D'Agostino has called a "sustainable nuclear deterrent" (D'Agostino 2008). The 2010 Nuclear Posture Review (NPR) stated that "to sustain a safe, secure, and effective U.S. nuclear stockpile as long as nuclear weapons exist, the United States must possess a modern physical infrastructurecomprised of the national security laboratories and a complex of supporting facilities." The NPR emphasized that "These investments are essential to facilitating reductions while sustaining deterrence under New START and beyond" (Department of Defense 2010b).

In May 2010, shortly after the signing of New START, NNSA delivered to Congress its Stockpile Stewardship Management Plan (SSMP) for FY11. The report identified numerous requirements of the new nuclear infrastructure, including the ability to undertake two or three simultaneous warhead life extension programs, instead 
of the current capability of one; the ability to produce 80 uranium canned subassemblies per year at Oak Ridge, as opposed to the current capacity of 40 ; and up to 80 plutonium pits per year at Los Alamos, versus the current rate of 10-20 (National Nuclear Security Administration 2010, 5). These new plutonium and uranium facilities were at the top of the list of the "essential investments" identified by the 2010 NPR; indeed, the NPR committed to having them come online by the year 2021 (Department of Defense 2010b).

The recommendations of what it would take to create a sustainable deterrent were, then, remarkably consistent across a broad, disparate, and bipartisan set of authorities. These include:

- the 2009 report of the bipartisan Strategic Posture Commission;

- the Obama administration's 2010 Nuclear Posture Review (NPR);

- the NNSA's 2010 Stockpile Stewardship and Management Plan (SSMP) report,

- the Senate's December 2010 resolution of ratification to the New START Treaty, requiring that the President certify that he would accelerate the new plutonium and uranium facilities to the extent possible, and continue to request full funding for their completion;

- an exchange of letters between President Obama and the top four Senate appropriators of both parties, in December 2010. The President's letter stated:

- "I recognize that nuclear modernization requires investment for the long-term ... that is my commitment to the Congress-that my administration will pursue these programs and capabilities for as long as I am president."

- the subsequent February 2, 2011 certifications by President Obama to the Senate:

- "I intend to (a) modernize or replace the triad of strategic nuclear delivery systems: a heavy bomber and air-launched cruise missile, an ICBM, and a nuclear-powered ballistic missile submarine (SSBN) and SLBM; and (b) maintain the United States rocket motor industrial base"; and further, that

- I intend to (a) accelerate, to the extent possible, the design and engineering phase of the [new plutonium and uranium facilities]; and (b) request full funding, including on a multi-year basis as appropriate, for the [buildings] ... upon completion of the design and engineering phase for such facilities."

- the update to the 1251 Report, delivered in November 2010, which stated that the construction for the new plutonium and uranium facilities would be complete by 2021, and would have full operational functionality by 2024 .

Based on all of these authorities and these numerous commitments, a bill called the New START Implementation Act (NSIA) identified each of these many metrics as goals that should be met both during the reductions in deployed forces planned under the New START treaty and as baselines to be demonstrated before further nonrequired reductions were made in the nondeployed hedge stockpile. Notwithstanding all this background and the bill's correspondence to their own stated goals and commitments, the administration threatened to veto the annual defense authorization act if it included the NSIA provisions (Executive Office of the President 2011).
The attempt to legislate the New START modernization bargain was, however, soon stymied by ordinary budgetary issues. As noted above, the Obama administration's updated "1251 Report" of November 2010 pledged a substantial level of funding for nuclear weapons activities by the NNSA. Before the New START treaty was signed, the Chairmen and Ranking Members of the full Appropriations Committee in the Senate, and the Senate Energy and Water Subcommittee on Appropriations, exchanged letters with the president pledging full support for these funding levels in the future. Unfortunately, the Appropriations Committees in the House of Representatives did not exchange these letters, and when it came time to appropriate NNSA for FY2012, the nuclear weapons activities account was cut by $\$ 440$ million (5.8\%), from $\$ 7.6$ to 7.1 billion. Because this was the first year of a 10-year commitment, it set a bad precedent.

More recent events further threaten the implementation of the New START modernization bargain. Following a departmentwide strategic review of defense requirements, on January 3, 2012 President Obama and Secretary Panetta released an overview of a new strategic defense plan, which briefly suggested that "It is possible that our deterrence goals can be achieved with a smaller nuclear force, which would reduce the number of nuclear weapons in our inventory as well as their role in U.S. national security strategy" (Department of Defense 2012b, emphasis original).

On January 25, 2012, Panetta unveiled a more detailed overview of defense cuts proposed for the coming decade. This document reaffirmed the coming fiscal year's protection of the nuclear Triad, but noted that the Ohio-class nuclear submarine replacement force would be delayed, creating challenges for maintaining current at-sea presence requirements in the 203os. The report also referenced the "ongoing" White House review of deterrence requirements, which "will address the potential for maintaining our deterrent with a different nuclear force" (Department of Defense 2012a). These statements lead some observers to be concerned that the administration's pre-New START commitment to a 10-year, $\$ 189$ billion investment for a truly sustainable nuclear deterrent now stands in jeopardy, and that the FY2013 request for weapons activities could be substantially reduced.

\section{THE ROLE OF CONGRESS}

In recent decades, Congress has tended to acquiesce to presidential leadership and preferences in the way of nuclear reductions. Historically, the size and shape of the US nuclear force has largely been "a function of presidential choice" (Perry and Schlesinger 2009, 23). The 1991 Presidential Nuclear Initiatives, for example, were nonbinding political arrangements that resulted, in part, in the withdrawal of thousands of US nuclear warheads from Europe, and the destruction of thousands more, without express statutory authorization from Congress, or the advice and consent of the Senate, to do so. In 2004, the George W. Bush administration directed that the nuclear stockpile be again be cut dramatically-by half-a goal reportedly met by 2007 (Trebes 2008). After the Cold War, congressional interest in US nuclear policy has waned, but this need not remain so. The New START Implementation Act (NSIA) of 2011 was one attempt in the 112th Congress to reassert congressional involvement in shaping the future of US nuclear policy.

The basis for more robust congressional involvement in US nuclear policy is straightforward. At times, both chambers of Congress have exercised oversight over the credibility, force structure, and policy, including, for example, nuclear force employ- 
ment issues implicated by a possible policy of a "no first use" doctrine. Separate from the role of the Senate in approving or rejecting arms control treaties, Congress played an important role in shaping nuclear policy and force structure during the Cold War. Should it wish to do resume such a role, Congress has ample legislative and appropriation authority to do so.
Donilon, Tom. 2011. Remarks at Carnegie Endowment for International Peace, March 29.

Executive Office of the President. 2010. "November 2010 Update to the National Defense Authorization Act of FY2010 Section 1251 Report: New START Treaty Framework and Nuclear Force Structure Plans."

Executive Office of the President. 2011. "Statement of Administration Policy: H.R. 1540-National Defense Authorization Act for FY 2012," May 24.

\section{Whether the post-New START path toward a sustainable nuclear deterrent will be implemented remains to be seen, but may depend on congressional vigilance.}

Speaking to Congress's relative inattention in recent years, the Strategic Posture Commission warned in particular about the adverse affects of the "chronic unwillingness of the Congress to support the programs needed to maintain [nuclear] test readiness," and warned of "evidence that some allies interpret the apparent lack of test readiness as a symptom of reduced U.S. commitment to extended deterrence" (Perry and Schlesinger 2009, 51). More robust congressional attention and involvement would be consistent with the commission's recommendation that "The practice and spirit of executive-legislative dialogue on nuclear strategy that helped pave the way for bipartisanship and continuity in policy should be renewed" (Perry and Schlesinger 2009, 15-16). Whether the post-New START path toward a sustainable nuclear deterrent will be implemented remains to be seen, but may depend on congressional vigilance.

\section{REFERENCES}

Cartwright, General James. 2010. Vice Chair, Joint Chiefs of Staff, "Responses to December 1, 2010 questions from Senator Jon Kyl,” December 6.

Chiles, General Henry (chair). 2008. Report of the Defense Science Board Task Force on Nuclear Deterrence Skills, September.

D'Agostino, Thomas. 2008. Remarks by NNSA Administrator at Nuclear Deterrent Summit, "Charting a Sustainable Course for the National Nuclear Security Enterprise." December 5. http://nnsa.energy.gov/mediaroom/speeches/ presented-nuclear-deterrent-summit- $\% \mathrm{E}_{2} \% 80 \% 9 \mathrm{Cch}$ arting-sustainable-coursenational-nuclear-

Department of Defense. 2010a. "Fact Sheet: Increasing Transparency in the U.S Nuclear Weapons Stockpile," May 3

Department of Defense. 2010b. Nuclear Posture Review Report, April.

Department of Defense, 2011. The Nuclear Matters Handbook. http://www.acq. osd.mil/ncbdp/nm/nm_book_5_11/index.htm

Department of Defense. 2012a. "Defense Budget Priorities and Choices," January.

Department of Defense. 2012b. "Sustaining U.S. Global Leadership: Priorities for 21st Century Defense," January.

Department of Defense and Department of Energy. 2008. National Security and Nuclear Weapons in the $21^{\text {st }}$ Century, September.

Department of State. 2011. "New START Treaty Aggregate Numbers of Strategic Offensive Arms," Fact Sheet, Bureau of Arms Control, Verification and Compliance, June 1.
Gates, Robert. 2008. "Nuclear Weapons and Deterrence in the $21^{\text {st }}$ Century," speech at the Carnegie Endowment, October 28.

Kristensen, Hans, Robert S. Norris, and Ivan Oelrich. 2009. From Counterforce to Minimum Deterrence: A New Nuclear Policy on the Path Toward Eliminating Nuclear Weapons. Washington, DC: Federation of American Scientists and Natural Resources Defense Council, April.

Perry, William R. 2009. “Chairman's Preface." In America's Strategic Posture: The Final Report of the Congressional Commission on the Strategic Posture of the United States. Washington, DC: United States Institute of Peace.

Perry, William R. (chair), and James R. Schlesinger (vice-chair). 2009. America's Strategic Posture: The Final Report of the Congressional Commission on the Strategic Posture of the United States. Washington, DC: United States Institute of Peace.

Pincus, Walter. 1978. "Scientists Bare Warhead Duds on '6os Polaris," Washington Post, December 2, A1.

Rosengren, Jack W. 1983. Some Little-Publicized Difficulties With a Nuclear Freeze, RDA-TR-122116-o01 Marina del Rey, CA: R\&D Associates, October.

Schlesinger, James R. 2009. "Statement of Dr. James Schlesinger." In In the Eyes of Experts; Analysis and Comments on America's Strategic Posture, Selected Contributions by the Experts of the Congressional Commission on the Strategic Posture of the United States. Washington, DC: United States Institute of Peace.

Schlesinger, James R. (chairman). 2008. Report of the Secretary of Defense Task Force on Nuclear Weapons Management: Phase II: review of the DoD Nuclear Mission, December. http://www.defense.gov/pubs/pdfs/PhaseIIReportFinal.pdf

Miller, James. 2011. Principal Deputy Under Secretary of Defense for Policy, testimony before the Senate Armed Services Strategic Forces Subcommittee, May 4.

National Nuclear Security Administration. 2010. Stockpile Stewardship and Management Plan (SSMP) Report for FY2011, Annex D. Washington, DC: Department of Energy, May 2010.

Obama, Barack. 2009. "Remarks by President Barack Obama, Hradcany Square, Prague, Czech Republic," April 5. http://www.whitehouse.gov/the_press_office/ Remarks-By-President-Barack-Obama-In-Prague-As-Delivered/

Obama, Barack. 2010. "Remarks by President Obama and President Medvedev of Russia at New START Treaty Signing Ceremony and Press Conference," April 8. http://www.whitehouse.gov/the-press-office/remarks-president-obama-andpresident-medvedev-russia-new-start-treaty-signing-cere

Tauscher, Ellen. 2011. "European Contributions to Nuclear Disarmament and Conflict Resolution," Remarks by the Under Secretary for Arms Control and International Security at the 59th Pugwash Conference on Science and World Affairs, Berlin, Germany, July 1.

Trebes, Jim. 2008. "Monitoring a Nuclear Weapon from the Inside," Science and Technology Review, July/August. 